\title{
PERAN ORGANISASI MAHASISWA DALAM MENINGKATKAN MUTU PEMBELAJARAN KETERAMPILAN BERBAHASA ARAB
}

\author{
Faisal Hendra \\ Universitas Al Az̧ar Indonesia, Indonesia \\ faisal_2104@uai.ac.id
}

\begin{abstract}
This article discusses how the student inter-organization of Arabic Literature study program in University of $\mathrm{Al}$ Azhar Indonesia takes role in enhancing quality of studying four Arabic language skills among students. This paper was focused on student organization mentoring pattern, type of program of activities formed by the organization, and the extent of students' active participation as organization member in running the program. This paper used qualitative descriptive method. This paper proposed: (1) The concept of kinship became the foundation for managing the organization, especially in the way it is operated. (2) Program of activities in the organization varied in a sense that some programs were in line so to support the purpose of learning Arabic skill, while there were also programs that did not consider Arabic fluency. However, the latter was designed to harness students soft skills, and develop students talent and interest. (3) The extent of students participation seems adequate, although some students did not yet play their expected functional role as member of student organization.
\end{abstract}

Keywords: $\quad$ role, student organization, teaching, fluency, university

\section{Abstrak}

Artikel ini membahas peran organisasi mahasiswa intra kampus Prodi Sastra Arab, Universitas Al-Azhar Indonesia (UAI) dalam meningkatkan mutu pembelajaran empat kemahiran berbahasa Arab mahasiswa, yang difokuskan kepada: pola pembinaan organisasi mahasiswa di Prodi Sastra Arab UAI, program kerja apa saja yang dibuat oleh pengurus organisasi dalam mendukung tujuan pembelajaran kemahiran berbahasa, dan melihat sejauh mana tingkat partisipasi mahasiswa sebagai anggota organisasi, aktif dalam menjalankan program kerja mereka. Penelitian ini bersifat deskriptif kualitatif. Hasil penelitian menunjukkan bahwa: (1) Konsep kekeluargaan dan profesionalisme menjadi dasar dalam mengelola organisasi mahasiswa intra kampus di Prodi Sastra Arab. (2) Program kerja organisasi mahasiswa beragam sifatnya, ada program yang selaras dan mendukung tujuan pembelajaran kemahiran berbahasa Arab, ada yang tidak berbasis kemahiran berbahasa, tetapi bermanfaat dalam menumbuh kembangkan softskill mahasiswa dan pengembangan minat-bakat. (3) Untuk partisipasi, keaktifan dan keikutsertaan mahasiswa yang tergabung di bawah organisasi mahasiswa Sastra Arab sudah cukup baik, walaupun masih ada beberapa orang yang belum menjalankan peran dan fungsinya.

Kata Kunci: peran, organisasi mahasiswa, pembelajaran, kemabiran, perguruan tinggi 


\section{Pendahuluan}

Keterampilan mendengar, berbicara, membaca dan menulis adalah empat keterampilan berbahasa yang harus dikuasai oleh mahasiswa yang memilih program studi Bahasa Arab sebagai tempat kuliah mereka di perguruan tinggi. Tidak saja di Prodi Sastra Arab, Fakultas Sastra, Universitas Al Azhar Indonesia (UAI), keterampilan berbahasa Arab juga menjadi tujuan utama dalam pembelajaran bahasa Arab di Universitas yang mengelola jurusan bahasa Arab nya di perguruan tinggi Indonesia.

Khusus di Prodi Sastra Arab UAI, tujuan pembelajaran bahasa Arab yang ingin dicapai adalah mengembangkan keterampilan berbahasa Arab mahasiswa dengan empat kemahiran yang ada, baik secara lisan maupun tulisan. Dengan keterampilan lisan, mahasiswa diharapkan mampu menguasai sejumlah kosakata dan struktur kalimat dan dapat berbicara secara aktif; dengan keterampilan menulis mahasiswa diharapkan mampu membaca, memahami, dan berdiskusi tentang teks berbahasa asing yang dipelajari, terutama yang berkaitan erat dengan materi yang dipelajari dan menuangkannya dalam bentuk tulisan. Adapun ruang lingkup pengajaran bahasa Arab secara umum meliputi; (a) unsur-unsur kebahasaan: tata bahasa, kosakata, pelafalan, dan ejaan, (b) keterampilan berbahasa: menyimak, berbicara, membaca, dan menulis, dan (c) aspek budaya yang terkandung dalam teks lisan dan tulisan.

Barakah menyatakan bahwa dalam pengajaran Bahasa Arab, ada lima unsur yang sangat mempengaruhi keberhasilan pengajaran bahasa Arab, kelima unsur ini adalah: tujuan pengajaran yang ingin dicapai dalam proses pembelajaran, bahan ajar yang digunakan, metode pengajaran dipakai, media pengajaran yang digunakan membantu dosen dalam mengajar, dan evaluasi akhir untuk melihat sejauh mana tingkat ketercapaian dari bahan ajar yang diajarkan. ${ }^{1}$

Dalam menjalankan kurikulum pendidikan di Universitas Al Azhar Indonesia, pelaksanaannya berada di bawah kendali pejabat struktur yang ada dibawah Universitas, mulai dari rektorat sampai tingkat pelaksana teknis di masing-masing program studi. Dosen adalah ujung tombak pelaksana kurikulum di tingkat pengajaran yang dilaksanakan. Ketua program studi bertanggung jawab dalam mengambil kebijakan dan melakukan langkah-langkah agar tercapainya tujuan pembelajaran bahasa Arab yang dilaksanakan, sementara dosen berperan melaksanakan proses belajar-mengajar dikelas, yang dimulai dengan membuat perencanaan, mengembangkan metodologi pengajaran, dan meningkatkan kompetensi keilmuannya dalam bidang bahasa. Pada saat yang sama mahasiswa sebagai objek penerapan kurikulum memiliki peran yang sangat penting demi tercapainya tujuan pengajaran yang ingin dicapai oleh program Studi, termasuk keberadaan organisasi berbasis program studi Arab, dimana mahasiswa, baik pengurus maupun anggota diharapkan mampu menterjemahkan kurikulum ini dengan berbagai aktivitas dan program kerja, mendukung tercapainya proses pengajaran bahasa Arab yang dilaksanakan. Ketiga

${ }^{1}$ Zaid Barakah, "diktat mata kuliah metodologi pengajaran bahasa Arab", International Institute for Arabic, Language, Khartoum, Sudan, 2000, 29. 
pihak inilah yang pada teorinya sangat menentukan tercapainya tujuan yang ingin dicapai dalam penerapan kurikulum, di Prodi Sastra Arab UAI.

Mahasiswa sebagai sasaran akhir dalam penerapan kurikulum yang dibuat oleh program studi dituntut untuk aktif dalam menterjemahkan setiap target yang ingin dicapai dalam proses pengajaran yang dilaksanakan Prodi. Sejauh mana mahasiswa aktif secara individu maupun organisasi mendukung proses pengajaran yang dilaksanakan, akan ikut menentukan keberhasilan proses pengajaran yang dilaksanakan. Secara teori mereka diajarkan bahasa Arab dikelas dengan pertemuan yang terstruktur. Seharusnya diluar kelas mahasiswa juga harus mengalokasikan waktu mereka mengembangkan dan mempraktekan bahan ajar yang dipelajari dikelas dalam bentuk atifitas harian, seperti diskusi kelompok, belajar mandiri atau bahkan kegiatan ekstra kurikuler yang bernuansa akademik, seperti lomba debat, game bahasa Arab, kuliah tamu untuk pembahasan tertentu dan lain sebagainya. Untuk melihat sejauh mana organisasi mahasiswa dari program studi sastra Arab, Universitas Al Azhar Indonesia menjadikan program kerja organisasi mereka sebagai bagian dari peningkatan kemampuan mereka dalam berbahasa Arab, maka dilakukanlah penelitian ini. Hasil penelitian ini diharapkan dapat menjadi bahan pengembangan pengajaran bahasa Arab mahasiswa Program Studi Sastra Arab UAI kedepannya.

\section{Kemampuan}

Mampu memiliki arti yang beragam, mampu bisa berarti kuasa, bisa atau sanggup untuk melakukan sesuatu, dapat, berada, kaya, mempunyai harta berlebih. Kemampuan adalah kesanggupan, kecakapan, kekuatan. Seseorang dikatakan mampu apabila ia bisa atau sanggup melakukan sesuatu yang harus ia lakukan untuk mendapatkan apa yang dia inginkan. Kemampuan adalah kapasitas seseorang dalam melakukan tugas dari suatu pekerjaan yang dilakukan. Bisa juga dikatakan bahwa kemampuan adalah sebuah penilaian akhir dari apa yang dapat dilakukan seseorang untuk mencapai satu tujuan.

Terkait dengan kemampuan, Robbins (2008) dalam bukunya mengatakan: "Motivation is the willingness to exert high levels of effort to reach organizational goals, conditioned by the effort's ability to satisfy some individual need". "Yang diterjemahkan kedalam bahasa Indonesia: "Motivasi merupakan suatu keinginan yang didukung oleh usaha yang tinggi untuk mencapai suatu tujuan organisasi, serta ditunjang oleh kemampuan untuk memuaskan kebutuhan masing-masing individu". Sementara Gipson mengatakan, kemampuan menunjukkan potensi orang untuk melaksanakan tugas atau pekerjaan. Kemampuan mungkin dimanfaatkan seseorang atau mungkin juga tidak. ${ }^{3}$ Kemampuan berhubungan sangat berhubungan erat dengan kemampuan fisik dan mental yang dimiliki seseorang untuk melaksanakan pekerjaan dan bukan yang ingin dilakukannya.

\footnotetext{
2, Stephen P Robbins dan Timothy A. Judge. Perilaku Organisasi, Buku 1, Jakarta: Salemba Empat. 2008), 56-66.

3 Gibson, Ivancevich, \& Donnely. Organisasi dan manajemen. Perilaku, struktur, proses. Edisi keempat. (Jakarta: Erlangga, 1994), 104.
} 
Berangkat dari pengertian kemampuan di atas peneliti dapat menyimpulkan bahwa, kemampuan adalah kecakapan atau potensi seseorang untuk memiliki dan menguasai keahlian tertentu dalam melakukan atau mengerjakan tugas dari suatu pekerjaan yang dilaksanakan, untuk mencapai sasaran akhir dari tujuan dilaksanakannnya tugas itu.

Pada dasarnya kemampuan terdiri dari:

1. kemampuan fisik, yaitu kemampuan seseorang melakukan tugas yang menuntut kepada stamina pelaku, keterampilan, kekuatan, dan karakteristik serupa ketika dia melaksanakan satu pekerjaan yang dilakukan.

2. kemampuan intelektual, yaitu kemampuan yang dibutuhkan seseorang dalam melakukan berbagai aktifitas mental, fikiran, nalar, analisa dan memecahkan masalah dari satu masalah yang dihadapi.

\section{Faktor Pendukung Kemampuan}

Faktor pendukung adalah segala sesuatu yang dapat mendorong atau mempengaruhi seseorang dalam meningkatkan kemampuan pembelajaran untuk menjadi lebih baik. Robbin ${ }^{4}$ menyatakan bahwa faktor pendukung kemampuan seseorang adalah sebagai berikut :

1. Faktor internal, yaitu faktor yang berasal dari dalam diri seseorang baik jasmani (fisiologis) maupun rohani (psikologis). Faktor fisiologis yaitu kondisi umum jasmani dan tonus (tegangan otot) yang menandai tingkat kebugaran organorgan tubuh dan sendi-sendinya dapat mempengaruhi semangat dan intensitas seseorang dalam mengikuti pelajaran.

2. Faktor eksternal, yaitu faktor yang berasal dari luar diri seorang. Faktor eksternal ini dibagi menjadi dua, yaitu lingkungan (yang berasal dari alam maupun sosial budaya) dan instrumental (fasislitas serta media yang disediakan di lembaga pendidikan).

\section{Belajar Bahasa}

Banyak kajian dilakukan untuk mengamati bagaimana anak memperoleh bahasa dalam lima tahun pertama dalam hidupnya. Di Indonesia, kajian semacam itu dilakukan oleh para pakar linguistik, diantaranya Sunjono Dardjowidjojo $(2000)^{5}$. Ia mengamati perkembangan bahasa cucunya yang bernama Echa selama lima tahun. Dalam lima tahun Echa, sang cucu ternyata telah dapat menguasai bahasa Indonesia yang dapat digunakan untuk berkomuniaksi. Studi semacam itu juga sudah banyak dilakukan oleh para pakar dari negara-negara Barat untuk menyingkap tabir rahasia anak belajar bahasa.

Dalam pembelajaran bahasa terdapat beberapa teori yang sangat berbeda pendapatnya. Kelompok pertama, yakni yang berorientasi pada psikologi

${ }^{4}$ Gibson \& Ivancevich \& Donnely. Organisasi dan manajemen. Perilaku, struktur, proses, 104.

${ }^{5}$ Soenjono, Dardjowidjojo. Psikolinguistik: Pengantar Pemahaman Bahasa Manusia, Jakarta: Yayasan Obor Indonesia, 2008). 
behaviorisme, yang kedua adalah pendekatan generatif yang berakar pada teori psikologi nativisme dan teori psikologi kognitivisme, sedangkan yang ketiga ialah pendekatan fungsional yang berakar pada psikologi konstruktivisme. Ketiga teori itu ternyata mempunyai pengaruh yang sangat kuat dalam dunia ilmu bahasa. Oleh sebab itu, ketiga teori itu akan kita bicarakan satu per satu dalam ulasan berikut ini.

\section{Teori Behaviorisme}

Bahasa merupakan bagian fundamental dari keseluruhan perilaku manusia. Demikianlah kaum behavioris melihat bahasa dan kaum behavioris mencoba untuk memformulasikan teori yang taat asas tentang pemerolehan bahasa pertama. Pendekatan behaviorisme memumpunkan perhatiannya pada aspek yang dapat dirasakan secara langsung pada perilaku berbahasa dan hubungan antara respons dan peristiwa di dunia yang mengelilinginya. Seorang behavioris menganggap bahwa perilaku berbahasa yang efektif merupakan hasil respons tertentu yang dikuatkan, respons itu akan menjadi kebiasaan atau terkondisikan. Jadi, anak dapat menghasilkan respons kebahasaan yang dikuatkan, baik respons yang berupa pemahaman atau respons yang berwujud ujaran. Seseorang belajar memahami ujaran dengan mereaksi stimulus secara memadai dan ia memperoleh penguatan untuk reaksi itu.

Salah satu percobaan yang terkenal untuk membentuk model perilaku berbahasa dari sudut pandang behavioris ialah yang dikemukakan oleh Skinner (1957) dalam Verbal Behaviour. Skinner dikenal dengan percobaannya tentang perilaku binatang yang terkenal dengan sebutan kotak Skinner. Teori Skinnner tentang perilaku verbal merupakan peluasan teorinya tentang belajar yang disebutnya operant conditioning. Konsep ini mengacu pada kondisi di mana manusia atau binatang mengirimkan respons atau operant (ujaran atau sebuah kalimat), tanpa adanya stimulus yang tampak. Operant itu dipertahankan dengan penguatan. Misalnya, jika seorang anak kecil mengatakan minta susu dan orang tuanya memberinya susu, operant itu dikuatkan. Dengan perulangan yang terus-menerus operant semacam itu akan terkondisikan. Menurut Skinner, perilaku verbal, seperti perilaku yang lain, dikendalikan oleh akibatnya. Bila akibatnya itu hadiah, perilaku itu akan terus dipertahankan dan kekuatan serta frekuensinya akan terus dikembangkan. Bila akibatnya hukuman, atau bila kurang adanya penguatan, perilaku itu akan diperlemah atau pelan-pelan akan disingkirkan.

Beberapa linguis dan ahli psikologi sependapat bahwa model Skinner tentang perilaku berbahasa dapat diterima secara memadai untuk kapasitas memperoleh bahasa, untuk perkembangan bahasa itu sendiri, untuk hakikat bahasa, dan untuk teori makna. Teori yang didasarkan pada penciptaan kondisi dan penguatan itu ternyata sulit untuk menjelaskan fakta bahwa ada kalimat baru yang kita ujarkan atau kita tulis yaitu kalimat yang tak pernah kita ujarkan atau kita tuliskan sebelumnya.

\section{Teori Generatif}

Pembicaraan tentang berbagai teori belajar bahasa itu dapat diibaratkan sebagai sebuah kontinuum. Di ujung yang satu berdiri tegak teori behaviorisme dan di ujung lain berdiri kukuh teori yang akan kita bahas sekarang ini, yakni teori generatif. Teori 
Ara6iyât Jurnal Pendidikan Bahasa Arab dan Kebahasaaraban, 5 (1), 2018

generatif mengguakan pendekatan rasionalistik. Teori itu melemparkan pertanyaan yang lebih dalam untuk mencari penjelasan yang gamblang dan jelas tentang rahasia pemerolehan dan belajar bahasa. Kegagalan atau setidak-tidaknya penjelasan yang masih bersifat parsial dari pandangan behaviorisme tentang bahasa anak-anak menyebabkan kita bertanya lebih banyak lagi. Tidak ada penelitian ilmiah yang menunjukkan kedalamannya dan ketuntasannya.

Ada dua tipe teori generatif yang telah membuat markanya masing-masing dalam penelitian bahasa. Keduanya beragih ujung yang sama pada kontinuum. Tipe pertama ialah golongan nativis dan kedua ialah golongan kognitivis.

\section{a. Nativisme}

Istilah nativisme dihasilkan dari pernyataan mendasar bahwa pembelajaran bahasa ditentukan oleh bakat. Bahwa kita dilahirkan itu sudah memiliki bakat untuk memperoleh dan belajar bahasa. Teori tentang bakat bahasa itu memperoleh dukungan dari berbagai sisi. Eric Lenneberg (1967) membuat proposisi bahwa bahasa itu merupakan perilaku khusus manusia dan bahwa cara pemahaman tertentu, pengkategorian kemampuan, dan mekanisme bahasa yang lain yang berhubungan ditentukan secara biologis.

\section{b. Kognitivisme}

Kerangka nativis pun masih mempunyai kelemahan-kelemahan. Akhir tahun 60-an merupakan saksi pergeseran kontinuum, tetapi bergerak lebih pada hakikat bahasa. Kaidah generatif yang diproposisikan oleh kelompok nativis itu nerupakan sesuatu yang abstrak, formal, eksplisit, dan logis, meskipun mereka berkaitan khususnya dengan bahasa dan buka tataran bahasa yang sangat dalam, pada tataran di mana ingatan, persepsi, pikiran, makna, dan emosi diorganisasikan secara berhubungan struktur super pikiran manusia.

\section{Organisasi Mahasiswa}

Organisasi mahasiswa intra kampus dapat diartikan adalah wadah berkumpulnya sekumpulan mahasiswa untuk mencapai tujuan bersama dalam satu organisasi, dan mempunyai visi dan misi yang jelas serta disetujui oleh semua pengurus organisasi tersebut. Organisasi mahasiswa intrakampus adalah organisasi mahasiswa yang memiliki kedudukan resmi di lingkungan perguruan tinggi dan mendapat pendanaan kegiatan kemahasiswaan dari pengelola perguruan tinggi dan atau dari kementerian atau lembaga terkait. Bentuknya dapat berupa organisasi mahasiswa ditingkat Universitas, organisasi kemahasiswaan tingkat Fakultas, organisasi kemahasiswaan tingkat Program Studi. Ada juga organisasi kemahaiswaan berdasarkan minat dan bakat mahasiswa, yang dinamakan dengan Unit Kegiatan Mahasiswa yang disingkat UKM.

Organisasi secara umum dipandang sebagai sebuah budaya, memberi peluang untuk penafsiran budaya. Sebuah organisasi bisa jadi merupakan cara pandang anggotanya, menciptakan realitas bersama yang berbeda dari budaya lainnya. Pemaknaan bersama, pemahaman bersama dan menciptakan perasaan bersama adalah 
cara yang berbeda untuk menggambarkan budaya. berbicara tentang budaya berarti berbicara tentang sebuah proses pembentukan realitas yang memungkinkan orang untuk melihat dan memahami kejadian khusus, tindakan, objek, ucapan dan situasi dalam cara yang unik. Budaya organisasi terbentuk melalui interaksi antar anggota dari organisasi yang bersangkutan.

Di Indonesia, organisasi mahasiswa intra kampus telah memiliki payung atau dasar hukum yang menjamin keberadaan, peran dan fungsinya dalam satu universitas, fakultas bahkan program studi. Payung hokum yang dimaksud adalah PP. No. 60 tahun 1999, tentang Perguruan Tinggi, yang kemudian secara teknis menguatkan Keputusan Menteri Pendidikan dan Kebudayaan Republik Indonesia No. 155/U/1998. Berbagai macam hal terkait dengan organisasi mahasiswa intra kampus dijelaskan dalam peraturan tersebut, baik dari kedudukan, fungsi, tugas, tanggung jawab, hingga persoalaan pendanaan dalam mengelola organisasi mahasiswa, yang berasal dan dialokasikan dari kampus atau sumber lain yang tidak bertentangan dengan peraturan perundang-undangan yang berlaku di negara kita Indonesia.

Secara umum ada beberapa manfaat organisasi kemahasiswaan bagi mahasiswa, dianataranya adalah:

1) Menjadi tempat dan sarana untuk mengembangkan ilmu pengetahuan yang dipelajari di program studi

2) Menjadi alat dalam melatih diri mempraktekan keilmuan formil yang dipelajari di kelas dan di kampus

3) Menumbuh kembangkan kemampuan sosial secara indifidu mahasiswa sebagai modal sebelum terjun kedalam kehidupan bermasyarakat

4) Menjadi pribadi yang kuat dalam menghadapi tekanan, baik pendidikan maupun luar pendidikan serta memiliki kemampuan untuk berkomunikasi dan beradaptasi dalam kehidupan sehari-hari

5) Meningkatkan wawasan dan pengetahuan, baik ilmu pendidikan yang dipelajari dikelas maupun ilmu penunjang penguat keilmuan masing-masing

6) Memperluas jejaring pergaulan mahasiswa dalam maupun luar kampus

7) Belajar mengatur menajemen waktu

8) Melatih dan menumbuhkan peran leadership seseorang atau kepemimpinan

9) Memperluas dan membangun jaringan dan kerjasama (networking) sekaligus menjadi tempat latihan sebelum masuk kedalam dunia kerja yang sesungguhnya ditengah masyarakat

Di samping manfaat di atas, beberapa universitas juga memiliki pola pembinaan yang menjadi kekhususan dari universitas yang bersangkutan dalam membina mahasiswa melalui organisasi mahasiswa intra kampus yang ada. ${ }^{6}$ Di Univeritas Al Azhar Indonesia misalnya, mereka tidak menggunakan kata Badan

${ }^{6}$ Azkia Muharom Albantani, Pembelajaran Bahasa Arab di UIN Syarif Hidayatullah Jakarta, (Ciputat: Cinta Buku Media, 2018), 265-269. 
Eksekutif Mahasiswa (BEM) untuk nama organisasi, akan tetapi lebih memiliha memasukan kata keluarga dimana organisasi mahasiswa. Untuk BEM UAI menggunakan nama Keluarga Mahasiswa Universitas, begitu juga organisasi ditingkat Fakultas, Prodi dan UKM. Begitu juga melibatkan Masjid Agung Al Azhar sebagai bagian yang tidak terpisahkan dari pembinaan organisasi mahasiswa UAI

\section{Metode Penelitian}

Penelitian ini menggunakan pendekatan kualitatif dengan analisis diturunkan dalam bentuk naratif. Populasi target adalah ketua dan sekretaris jurusan program studi Sastra Arab UAI, pengurus organisasi mahasiswa dibawah program studi Sastra Arab UAI yang menjadi pengurus organisasi mahasiswa Prodi Sastra Arab UAI tahun akademik 2016-2017, ditambah dengan beberapa orang mahasiswa yang bukan pengurus untuk dilakukan wawancara. Analisis penelitian mengacu kepada pembinaan organisasi mahasiswa dan pembuatan program kerja tahunan dan korelasinya dengan kurikulum pembelajaran kemahiran berbahasa Arab yang dilaksanakan di Prodi Sastra Arab UAI.

Peneliti menggunakan dua teknik pengumpulan data, wawancara dan observasi, dengan pedoman masing-masing. Untuk responden peneliti juga membagikan angket untuk diisi oleh objek, dari pengurus organisasi mahasiswa Prodi Sastra Arab UAI.

\section{Hasil Penelitian}

\section{Organisasi Mahasiswa Intra Kampus di Universitas Al Azhar Indonesia}

Universitas Al Azhar Indonesia (UAI), didirikan pada tahun 2000, dari segi umur universitas yang masih tergolong masih muda, pada tahun 2018 berumur 18 tahun. Dalam menjalankan peran dan fungsinya, Universitas Al Azhar Indonesia telah berusaha semaksimal mungkin memberikan yang terbaik kepada mahasiswanya, dalam memperkaya kemampuan bardskill dan softskill mereka, baik melalui pendidikan terstruktur maupun dalam bentuk kegiatan organisasi mahasiswa intra kampus. Di antara bentuk terobosan yang dilakukan oleh universitas adalah, sebagaimana yang sudah disinggung di atas, pada tahun 2005, UAI membuat ciri khusus bagi organisasi mahasiswa intra kampus di UAI. Di luar sana universitas lain menggunakan kata dan sistem PRESMA (Presiden Mahasiswa). UAI menggunakan konsep kekeluargaan dengan memilih nama KMU (Keluarga Mahasiswa Universitas), begitu juga ditingkat fakultas, program studi dan organisasi berbasis minat dan bakat. Pemberian nama selalu mencantumkan kata keluarga, dengan asumsi bahwa mahasiswa dalam organisasi mereka, pengelolaannya harus dibangun dengan dua semangat, semangat profesionlisme pengelolaan organisasi atas dasar semangat kekeluargaan. Maka di UAI dinamakanlah organisasi ditingkat fakultas dengan nama Keluarga Mahasiswa Fakultas (KMF), ditingkat program studi dinamakan Keluarga Mahasiswa Program Studi (KMPS) dan untuk organisasi minat bakat dinamakan Unit Keluarga Kegiatan Mahasiswa (UKKM).

Dalam menjalankan roda organisasi KMU, KMF, KMPS dan UKKM harus bercirikan 7 elemen dasar UAI sebagai nilai-nilai unggulan yang dikembangkan oleh 
UAI, khususnya dalam penerapan nilai-nilai keislaman, dimana sebagai sebuah keluarga, sebuah organisasi dapat dibina dengan semangat profesionalisme dan kekeluargaan dan jika ada dinamika, atau perbedaan yang timbul dalam perjalanannya, diharapkan dapat ditempuh usaha-usaha kekeluargaan dalam menyelesaikannya. Konsep ini tidak saja untuk organisasi mahasiswa akan tetapi juga untuk beberapa lembaga lainnya di bawah Universitas.

\section{Keluarga Mahasiswa Fakultas Sastra dan Program Studi}

Organisasi kemahasiswan di Fakultas Sastra, dibagi kedalam dua jenis. Organisasi mahasiswa di tingkat Fakultas, sebagaimana kami sampaikan di atas diberi nama Keluarga Mahasiswa Fakultas Sastra (KMFS) dengan Dekan Fakultas sebagai pembinanya, dan organisasi mahasiswa di tingkat program studi yang diberinama dengan Keluarga Mahasiswa Program Studi (KMPS) dengan Ketua Program Studi sebagai pembinanya.

Di antara tugas organisasi mahasiswa di tingkat Fakultas dalam pembinaan organisasi mahasiswa dan anggota di Fakultas adalah:

1) Merencanakan dan melaksanakan kegiatan organisasi kemahasiswaan tingkat Fakultas berdasarkan semangat pengelolaan Tridharma Perguruan Tinggi dan Visi Misi Universitas Al Azhar Indonesia di tingkat Fakultas Sastra.

2) Membuat dan melaporkan kegiatan kemahasiswaan kepada Koordinator Kemahasiswaan, Dekan, dan Direktorat Kemahasiswaan tingkat Universitas sesuai dengan syarat dan ketentuan yang telah ditentukan oleh universitas.

3) Melakukan koordinasi kegiatan kemahasiswaan dengan Fakultas sebagai penanggung jawab pembinaan mahasiswa tingkat Fakultas.

4) Menyelenggarakan program kerja masing-masing devisi, melaksanakan kaderisasi dan pemilihan pengurus, dan bentuk kegiatan lainnya.

5) Ikut terlibat dalam kegiatan lomba, penelitian, seminar, workshop dan sebagainya, di tingkat Fakultas, universitas, nasional, maupun tingkat internasional.

6) Melakukan kaderisasi tingkat Fakultas dan lintas Prodi untuk menjaga kesinambungan kepemimpinan organisasi mahasiswa di Fakultas Sastra.

Sementara peran organisasi mahasiswa ditingkat Program Studi, adalah:

1) Merencanakan dan melaksanakan kegiatan kemahasiswaan yang yang tergabung dibawah organisasi mahasiswa tingkat program studi, yang berkaitan dengan pengembangan penalaran dan keilmuan serta sikap, profesi sesuai bidang ilmu dan program studi, yang sesuai visi misi Universitas Al Azhar Indonesia dan Tridharma perguruan tinggi.

2) Menyelenggarakan proses kaderisasi organisasi tingkat Program Studi

3) Ikut aktif mengikuti kegiatan lomba-lomba, penelitian dan dan tri dharma perguruan tinggi di tingkat program studi, fakultas, universitas, nasional, maupun internasional.

4) Membuat dan melaporkan laporan pertanggung jawaban seluruh kegiatan kemahasiswaan di bawah organisasi mahasiswa kepada Ketua Program Studi. 


\section{Pembahasan}

Data penelitian ini dibagi ke dalam empat bagian, yaitu: Pertama, pandangan pengurus organisasi terkait keberadaan organisasi dan cara mereka dalam membuat program kerja. Kedua, pandangan pengurus organisasi dalam membuat program kerja sebagai alat untuk meningkatkan kemahiran berbahasa Arab mereka di Prodi Sastra Arab. Ketiga, Program kerja organisasi mahasiswa intra kampus di bawah Prodi Sastra Arab, yang mendukung pengajaran kemahiran mendengar, berbicara, membaca, dan menulis. Keempat, pendapat mahasiswa sebagai pengurus secara umum tentang peran organisasi kemahasiswaan yang ideal yang perlu dikembangkan di Prodi Sastra Arab selanjutnya, dalam meningkatkan kemampuan kemahiran berbahasa Arab mahasiswa.

\section{Pandangan Pengurus Organisasi}

\section{Keberadaan Organisasi dan Cara Membuat Program Kerja Organisasi}

Keberadaan organisasi mahasiswa di Prodi Sastra Arab UAI merupakan sebuah keharusan. Organisasi adalah wadah bagi para mahasiswa untuk bisa mengekspresikan diri dan menyampaikan aspirasi yang mereka miliki. Setelah dilakukan penelitian didapatkan data bahwa, mayoritas pengurus organisasi mahasiswa di bawah Prodi Sastra Arab mengatakan bahwa keberadaan organisasi sangat penting ada di tingkat program studi, fakultas bahkan universitas, karena dengan adanya organisasi akan bisa menampung banyak ide dan pengembangan kreativitas seluruh mahasiswa. Mahasiswa Prodi Sastra Arab sangat menyadari bahwa organisasi bisa digunakan sebagai tempat atau wadah tempat mahasiswa berkumpul, bekerjasama secara rasional dan sistematis, terencana, terorganisasi, terpimpin dan terkendali, dalam memanfaatkan sumber daya, sarana-parasarana, data dan lain sebagainya yang digunakan secara efisien dan efektif untuk mencapai tujuan organisasi yang mereka kelola. Apalagi keberadaan organisasi berbasis keilmuan yang dipelajari. Dengan tergabungnya mahasiswa di bawah satu wadah, mereka akan merasa lebih terpanggil untuk berkontribusi dalam bidang kebahasaaan yang mereka pelajari, sulit untuk memisahkan antara berorganisasi hanya untuk melatih softskill sementara pada saat yang bersamaan mereka juga dituntut untuk berprestasi di bidang akademik, khususnya di keterampilan berbahasa. Maka akhirnya menjadi keharusan untuk menyelaraskan keberadaan mereka di organisasi dengan peran mereka sebagai mahasiswa program studi.

Muncul pertanyaan, bagaimana menjadikan organisasi mahasiswa sebagai bagian dari alat dalam membantu proses pembelajaran keterampilan berbahasa? Data menunjukkan bahwa tingkat kesadaran mahasiswa Prodi Sastra Arab UAI berorganisasi secara umum sudah baik, mereka menyadari bahwa tidak mungkin organisasi mereka bisa berjalan kalau bukan mereka yang menjalankannya. Juga tidak akan mungkin program kerja yang telah dibuat bisa berjalan, kalau bukan dijalankan oleh mereka sendiri sebagai pengurus organisasi. Secara umum kesadaran penting bergabung dalam satu wadah organisasi, dan seorang pengurus harus membuat program kerja organisasi sebagai konsekwen keberadaan mereka sebagi pengurus, sudah tertanam dalam diri mahasiswa Prodi Sastra Arab UAI dengan baik, bahkan ketika membuat program kerja tahunan mahasiswa sudah berusaha untuk membuat 
program kerja tidak bekerja secara indifidu. Untuk membuat program kerja ini mereka membuatnya dengan beberapa tahapan, diawali dengan melibatkan para anggota, kemudian minta saran dan pendapat dari kakak tingkat, minta saran kepada program studi, bahkan mereka juga membangun komunikasi dengan organisasi lain yang ada di bawah Fakultas dan Prodi lain yang ada di UAI.

Dalam buku Effective Public Relations, Glen menyebutkan bahwa pembuatan program kerja sebuah organisasi harus melalui empat proses yang harus dilewati yaitu: ${ }^{7}$

a) Research Listening, atau Penelitian dan Mendengarkan. Dalam tahap ini pengurus organisasi harus mempelajari opini, sikap dan reaksi publik terkait terhadap kebijakan atau produk organisasi yang direncanakan dan akan dilaksanakan.

b) Planning Decission, atau Perencanaan pengambilan keputusan. Di poin ini pengurus organisasi harus bisa memberikan sikap, opini, ide, dan reaksi yang berkaitan dengan kebijaksanaan yang akan dilahirkan. Saat dilakukan penetapan program, kerja organisasi harus sejalan dengan kepentingan atau keinginan pihak yang berkepentingan.

c) Communication Action, atau Mengkomunikasikan dan Pelaksanaan. Pengurus organisasi harus menjelaskan informasi mengenai langkah yang akan ditempuh oleh organisasi, dan diharapkan apa yang diputuskan bisa mempengaruhi pihak-pihak tertentu yang penting dan berpotensi mendukung program organisasi.

d) Evaluation, atau Mengevaluasi. Pengurus organisasi diharapakan mengadakan penilaian dan evaluasi terhadap program dan hasil kerjas yang dilakukan

Beberapa hal di atas dapat ditafsirkan bahwa para pengurus harus melakukan tahapan di bawah ini dalam membuat program kerja organisasi, yaitu: ${ }^{8}$

1) Melihat dan menganalisis prilaku umum dan hubungan organisasi terhadap lingkungan dimana organisasi itu berada.

2) Menentukan dan memahami secara benar prilaku anggota terhadap organisasi.

3) Menganalisasi tingkat opini publik, baik internal maupun eksternal.

4) Mengantisipasi kemungkinan-kemungkinan yang muncul.

5) Menentukan formulasi dan merumuskan program kerja.

6) Membuat anggaran biaya operasional program kerja.

7) Menjalankan dan melaksanakan program kerja.

8) Melakukan evaluasi dan penyesuaian yang diperlukan.

Guna untuk mendapatkan hasil maksimal, maka semua tahapan di atas dalam mengelola organisasi harus senantiasa dilaksanakan dengan baik.

\section{Program Kerja Sebagai Alat untuk Meningkatan Kemahiran Berbahasa}

Program kerja organisasi mahasiswa Prodi Sastra Arab harus memenuhi empat syarat di bawah ini:

7 Glen M. Broom, Cutlip and Center's, Effective Public Relations: International Edition, edisi 11, (Pearson Education Limited, 2013).

${ }^{8}$ Glen M. Broom, Cutlip and Center's, Effective Public Relations: International Edition. 
a. Program kerja organisasi mahasiswa prodi sastra Arab yang dibuat, harus menampung seluruh potensi yang ada dari seluruh anggota

b. Program kerja organisasi mahasiswa prodi sastra Arab harus menunjang proses belajar mengajar yang diajarkan di Program Studi

c. Program kerja organisasi mahasiswa prodi sastra Arab harus mendukung mahasiswa untuk bisa menggunakan empat kemahiran berbahasa dengn baik

d. Program kerja organisasi mahasiswa prodi sastra Arab harus sejalan dengan arah pengajaran yang dikembangkan oleh Program Studi Sastra Arab.

'Kuliah' dan 'Organisasi' adalah dua kegiatan yang tidak dapat dipisahkan dari kehidupan mahasiswa. Masing-masing mahasiswa memiliki hak untuk aktif dalam suatu organisasi ataupu tidak aktif. Dalam bahasa sastra dikatakan kuliah tanpa organisasi bagaikan kerupuk yang jika dimakan hanya mendapat anginnya saja. Mahasiswa hanya belajar teori di dalam kelas tanpa mampu mengaplikasikannya di dalam kehidupan sehari-hari di masyarakat. Begitu juga bagi yang sangat aktif dalam berorganisasi. Terlalu mengutamakan organisasi hingga melalaikan kuliah bagai pohon yang tidak berdaun. Menjadi bagian dari lingkungan baru dalam suatu organisasi, tentunya membuat mahasiswa harus mampu beradaptasi dengan kehidupan yang baru. Begitu juga dengan kehidupan mereka kampus. Segala macam karakter orang terdapat dalam dunia kampus. Jati diri sebagai mahasiswa akan semakin diperhitungkan. ${ }^{9}$

Ada pertanyaan yang muncul dari mahasiswa apakah berorganisasi menjadi salah satu kewajiban tambahan bagi seorang mahasiswa yang belajar di perguruan tinggi?. Untuk menjawab pertanyaan, ini peneliti lebih setuju mengatakan bahwa berorganisasi itu adalah pilihan masing-masing mahasiswa, tidak ada jaminan bagi mereka yang aktif berorganisasi akan memperoleh kesuksesan dalam prestasi akademik. Begitu juga sebaliknya, tidak ada jaminan bagi mereka yang aktif berorganisasi akan mengalami kegagalan dalam prestasi akademik. Justru pendapat yang banyak mengatakan tidak ada korelasi antara keduanya. ${ }^{10}$ Hal ini diperkuat dengan hasil penelitian Kurniawati dan Leonardi yang menjelaskan bahwa tidak terdapat hubungan antara metakognisi dengan prestasi akademik pada mahasiswa yang aktif berorganisasi di tingkat fakultas. ${ }^{11}$

Terkait dengan poin ini, didapatkan data bahwa pengurus organisasi mahasiswa di Prodi Sastra Arab dalam menyikapi empat pernyataan di atas, hampir

9 Yasinta Karina Caesari, Anita Listiara, Jati Ariati, "Kuliah versus Organisasi: Studi Kasus Mengenai Strategi Belajar Pada Mahasiswa yang Aktif dalam Organisasi Mahasiswa Pecinta Alam Universitas Diponegoro", Jurnal Psikologi Undip, Vol.12 No.2, 2013, 164-175.

${ }^{10}$ Betie Febriana, dkk., "Hubungan Antara Keaktifan Organisasi dengan Prestasi Belajar (Indeks Prestasi) Mahasiswa Fakultas Ilmu Keperawatan Universitas Indonesia”, Prosiding Konferensi Nasional PPNI Jawa Tengah, 2013, 154-157.

11 Rosi Kurniawati dan Tino Leonardi, "Hubungan Antara Metakognisi dengan Prestasi Akademik pada Mahasiswa Fakultas Psikologi Universitas Airlangga yang Aktif Berorganisasi di Organisasi Mahasiswa Tingkat Fakultas", Jurnal Psikologi Pendidikan dan Perkembangan, Vol. 2, No. 01, 2013, 18 . 
seluruh pengurus menyatakan bahwa dalam membuat program kerja, merupakan sebuah keharusan bagi mereka mengkaji kekuatan apa saja yang dimiliki oleh para anggota sebelum program kerja ini dibuat. Mereka juga sangat setuju jika keberadaan program kerja yang dibuat oleh pengurus organisasi mahasiswa harus menunjang proses belajar mengajar yang diajarkan di Program Studi, harus sejalan dan saling mendukung. Mereka merasa program kerja yang dibuat harus menunjang dan mendukung penguasaan keterampilan berbahasa Arab yang dipelajari. Maka program kerja organisasi harus sejalan dengan arah pengajaran yang dikembangkan oleh Program Studi, dengan tetap mengedepankan kebebasan berpendapat dan berkreasi mahasiswa. Mereka perlu dibina dan diarahkan, jangan sampai terlena dan salah menempatkan, kapan harus aktif berorganisasi dan kapan waktu untuk belajar. Idealnya adalah kegiatan belajar dan berorganisasi harus saling mendukung antara keduanya.

\section{Program kerja yang mendukung pembelajaran keterampilan berbahasa}

Organisasi mahasiswa Prodi Sastra Arab UAI melaksanakan beberapa program kerja yang mendukung proses pembelajaran keterampilan berbahasa pada tahun akademik 2016/2017. Ada kegiatan yang murni berbasis keterampilan berbahasa, ada juga kegiatan yang konsep awalnya bukan untuk memperkuat keterampilan berbahasa, akan tetapi dipelaksanaannya menggunakan Bahasa Arab yang mereka pelajari. Ada juga beberapa kegiatan yang tidak berhubungan dengan pengajaran keterampilan berbahasa dan pengembangan keilmuan lainnya. Di antara program kerja tersebut adalah:

\begin{tabular}{|c|c|c|}
\hline No & Bidang/Devisi & Program Kerja \\
\hline 1 & $\begin{array}{l}\text { Ketua dan Wakil } \\
\text { KMPS Arab }\end{array}$ & $\begin{array}{l}\text { 1) Mengondisikan bagi seluruh bidang yanga ada agar } \\
\text { membuat program kerja, di samping keahlian lain, juga } \\
\text { harus membuat program yang berhubungan dengan } \\
\text { kemahiran bahasa } \\
\text { 2) Memantau dan mengawal jalannya program kerja yang } \\
\text { berhubungan dengan kemahiran bahasa }\end{array}$ \\
\hline 2 & $\begin{array}{l}\text { Sekretaris dan } \\
\text { Bendahara KMPS } \\
\text { Arab }\end{array}$ & $\begin{array}{l}\text { 1) Membuat surat tertentu sesuai kebutuhan organisasi } \\
\text { menggunakan bahasa Arab } \\
\text { 2) Mengajarkan anggota pengurus dan non pengurus } \\
\text { dalam surat menyurat dalam bahasa Arab }\end{array}$ \\
\hline 3 & Divisi Humas & $\begin{array}{l}\text { 1) Membuat mading sebagai alat kreasi menulis } \\
\text { mahasiswa menggunakan bahasa Arab } \\
\text { 2) Menyediakan wadah untuk pengurus dan non } \\
\text { pengurus (anggota) untuk menulis dengan } \\
\text { menggunakan bahasa Arab di mading yang telah } \\
\text { disediakan }\end{array}$ \\
\hline 4 & $\begin{array}{l}\text { Divisi PENSI } \\
\text { (Pendidikan dan }\end{array}$ & $\begin{array}{l}\text { 1) Mengadakan Yaumul 'Arabi atau hari bahasa Arab } \\
\text { setiap hari rabu sore untuk melatih kemahiran }\end{array}$ \\
\hline
\end{tabular}


Arabiyât Jurnal Pendidikan Bahasa Arab dan Kebahasaaraban, 5 (1), 2018

\begin{tabular}{|c|c|c|c|}
\hline & Kontribusi) & 2) & $\begin{array}{l}\text { berbahasa mahasiswa sastra Arab UAI } \\
\text { Mengadakan kursus dan lomba mengetik bahasa Arab } \\
\text { yang diperuntukan bagi seluruh pengurus dan anggota } \\
\text { KMPS Arab UAI. } \\
\text { Melatih dan memperlancar serta membantu mahasiswa } \\
\text { dalam materi percakapan bahasa Arab ketika } \\
\text { dilaksanakan acara Yaumul 'Arabi atau hari bahasa Arab } \\
\text { Melaksanakan acara seminar tentang kebahasaan bagi } \\
\text { mahasiswa, tingkat nasional mengenai bahasa Arab dan } \\
\text { hal-hal terkait dengan belajar kemahiran berbahasa }\end{array}$ \\
\hline 5 & $\begin{array}{l}\text { Divisi MIKAT } \\
\text { (Minat dan Bakat) }\end{array}$ & 1) & $\begin{array}{l}\text { Membuat kelompok/komunitas, dari berbagai bidang } \\
\text { keahlian, seperti jurnalisme, kaligrafi, debat, puisi, } \\
\text { menyanyi dalam bahasa Arab bagi pengurus dan non } \\
\text { pengurus KMPS Arab. } \\
\text { Mengikuti perlombaan dan pertandingan baik loka, } \\
\text { nasional dan internasional yang berhubungan dengan } \\
\text { kemahiran berbahasa Arab } \\
\text { Mengadakan acara Festival Arabia, yaitu perlombaan } \\
\text { nasional mengenai bahasa Arab tingkat SMA dan } \\
\text { Perguruan Tinggi satu kali dalam satu tahun }\end{array}$ \\
\hline 6 & $\begin{array}{l}\text { Devisi SAGA } \\
\text { (Sosial dan } \\
\text { Agama) }\end{array}$ & 1) & $\begin{array}{l}\text { Mengadakan acara Himpunan Mahasiswa Sastra Arab } \\
\text { (HIMASA) mengajar, yaitu kegiatan mengajar bahasa } \\
\text { Arab kepada anak-anak TPA dan anak yang } \\
\text { mebutuhkan }\end{array}$ \\
\hline
\end{tabular}

Data di atas menunjukkan bahwa organisasi mahasiswa merencanakan dan menyelenggarakan cukup banyak program kerja yang menunjang proses pembelajaran keterampilan berbahasa Arab di Prodi Sastra Arab. Walaupun masih beragam bentuk, jumlah, dan program antara masing-masing divisi yang ada. Ada yang menjadikan keterampilan sebagai subjek/fokus kegiatan, ada juga yang menjadikan keterampilan berbahasa Arab sebagai tujuan pendamping.

Di samping pengurus harian yang menjalankan peran dan fungsinya sebagai orang yang ditugasi mengelola berjalannya roda organisasi, ada empat devisi yang dijadikan ujung tombak mengawal jalannya roda organisasi dengan program-program mereka yang beragam. Sebagaimana yang tergambar di tabel diatas, keempat devisi ini adalah: Devisi Hubungan Masyarakat (Humas), Pendidikan dan Kontribusi (Pensi), Minat dan Bakat (Mikat) dan Devisi Sosial dan Agama (Siaga). Dari empat devisi ini setidaknya ada 9 program kerja tahunan yang dilaksanakan yang menunjang tercapainya tujuan pengajaran kemahiran berbahasa Arab yang dilaksanakan oleh Program Studi. Ada program yang dilaksanakan satu kali selama masa kepengurusan, dan ada juga yang dilaksanakan satu kali dalam seminggu, berupa kegiatan rutin mingguan yang melibatkan seluruh pengurus dan anggota dalam mengasah kemampuan mereka menggunakan bahasa Arab. Ke-sembilan program ini adalah: 
1) Membuat mading yang digunakan sebagai alat untuk menuangkan kreasi menulis mahasiswa menggunakan bahasa Arab yang diganti secara berkala sesuai dengan kebutuhan mahasiswa.

2) Mengadakan Yaumul 'Arabi atau hari bahasa Arab, yang disepakati setiap hari Rabu pukul 16.00 sd 18.00 WIB, untuk melatih kemahiran berbahasa Arab mahasiswa yang tema nya disepakati berubah dari minggu ke minggu, kadang kemahiran berbicara, membaca dan kadang kemahiran menulis. Tidak saja hanya kemahiran yang empat, kadang juga ada keilmuan lain penunjang mata kuliah, seperti kaligrafi, latihan debat dan kegiatan lainnya.

3) Mengadakan kursus dan lomba mengetik bahasa Arab yang diperuntukan bagi seluruh pengurus dan anggota KMPS Arab UAI. Kegiatan ini penunjang mata kuliah IT Arab, dimana para mahsiswa diajarkan untuk mampu mengetik Arab dengan baik dan dengan kecepatan sebagaimana mengetik Bahasa Indonesia.

4) Melatih dan memperlancar serta membantu mahasiswa dalam materi percakapan bahasa Arab ketika dilaksanakan acara Yaumul 'Arabi atau hari bahasa Arab. Mahasiswa berusaha berinovasi dalam memotivasi temannya untuk mampu berbicara bahasa Arab. Bagi mahasiswa yang kelihatan lemah dalam kemahiran berbahasa, akan dipantu oleh kakak tingkatnya, untuk selanjutnya akan dikelompokan dan diberikan pendekatan khusus, untuk didorong di pertemuan berikutnya mampu menggunakan bahasa Arab sebagai bahasa komunikasi.

5) Melaksanakan acara seminar tentang kebahasaan bagi mahasiswa, tingkat nasional mengenai bahasa Arab dan hal-hal terkait dengan belajar kemahiran berbahasa.

6) Membuat kelompok/komunitas, dari berbagai bidang keahlian, seperti jurnalisme, kaligrafi, debat, puisi, serta menyanyi dalam bahasa Arab bagi pengurus dan non pengurus KMPS Arab. Kegiatan ini juga kadang diikuti oleh mahasiswa lintas prodi yang ada di UAI.

7) Mengikuti perlombaan dan pertandingan baik lokal, nasional dan internasional yang berhubungan dengan kemahiran berbahasa Arab. Di antara kegiatan yang sering diikuti oleh mahasiswa prodi Sastra Arab UAI adalah, MTQ, Lomba Debat, Baca Berita, Pidato, Kaligrafi dan kegiatan-kegiatan akademik lainnya.

8) Mengadakan acara Festival Arabia, yaitu perlombaan nasional mengenai bahasa Arab tingkat SMA dan Perguruan Tinggi satu kali dalam satu tahun. Ada dua manfaat langsung dari lomba ini, selain mengasah kemahiran berbahasa Arab mahasiswa, juga mereka dilatih untuk menjadi panitia pelaksana yang tentunya bermanfaat untuk melatih kepemimpinan dan tanggung jawab merka dalam melaksanakan kegiatan.

9) Mengadakan acara Himpunan Mahasiswa Sastra Arab (HIMASA) mengajar, yaitu kegiatan mengajar bahasa Arab kepada anak-anak TPA dan anak yang membutuhkan, yang dilaksanakan menimal 2 kali dalam setahun, semester ganjil dan semester genap.

Di samping program-program yang selaras dengan tujuan pengajaran kemahiran berbahasa di program studi sebagaimana yang dijelaskan diatas, ternyata 
masih ada bidang/devisi yang membuat dan menjalankan program kerjanya, akan tetapi tidak ada korelasinya dengan tugas yang diembannya dalam organisasi. Hal ini membuktikan kepada peneliti bahwa masih perlu dilakukan pendampingan bagi mahasiswa pengurus organisasi dalam mengelola organisasi di Prodi Sastra Arab UAI.

Hasil observasi dan wawancara berbagai sumber di beberapa universitas sekitar Jakarta, seperti Universitas Negeri Jakarta (UNJ), Universitas Islam Jakarta (UIJ), Universitas Indonesia (UI), dan Universitas Islam Negeri (UIN) Syarif Hidayatullah, menunjukkan bahwa kondisi pengelolaan organisasi mahasiswa intra kampus prodi Sastra Arab UAI tidak jauh berbeda dengan apa yang didapatkan di universitas lainnya, walaupun untuk beberapa program kerja berbasis kemahiran berbahasa Arab ada organisasi mahasiswa yang pengelolaannya lebih baik dibandingkan dengan yang ada di UAI, seperti kelompok Debating Club di UIN Jakarta, Komunitas Budaya di UI dan beberapa program kerja lainnya dari berbagai universitas yang ada. Tetapi secara umum gambaran pengelolaan program kerja organiasasi intra mahasiswa berbasis kemahiran berbahasa tidak jauh berbeda antara satu universitas dengan yang lainnya yang ada di Jakarta.

\section{Peningkatan kemampuan kemahiran berbahasa Arab melalui organisasi mahasiswa}

Pada bagian akhir penelitian ini, telah dirangkum usulan dari pengurus organisasi mahasiswa untuk meningkatkan kemampuan mahasiswa dalam keterampilan berbahasa Arab, sebagai berikut:

1. Pengurus harus membuat program kerja dengan memperbanyak kegiatan dalam menumbuhkan dan mengembangkan potensi mahasiswa khusus nya di bidang keterampilan berbahasa.

2. Sudah seharusnya organisasi mahasiswa berjalan seiringan dengan apa yang menjadi tanggung jawab program studi dalam menyiapkan mahasiswa untuk menguasai keterampilan berbahasa, sehingga bisa menjadi penyeimbang dan mendukung pembelajaran yang dilaksanakan di dalam kelas.

3. Program kerja yang dibuat harus selaras dengan visi dan misi program studi dalam mengajarkan bahasa Arab dan budayanya. Kegiatan yang dilakukan di luar kelas diharapakan bisa membantu mahasiswa menguasi keilmuan yang dipelajari di dalam kelas.

4. Dalam melaksanakan program yang sudah disepakati, pengurus perlu membuat strategi yang tepat agar anggota lebih aktif berorganisasi atas kesadaran dan keinginan sendiri dan bukan karena paksaan untuk aktif.

5. Program kerja yang dibuat diharapkan mampu mengeksplor kemampuan bahasa Arab para mahasiswa dengan pendekatan dan metode yang tepat dan menyenangkan.

6. Organisasi mahasiswa harus mampu menempatkan posisinya sebagai mitra program studi dalam mencapai tujuan pembelajaran yang hendak dicapai. Di 
samping melatih diri dalam pengembangan softskill, ${ }^{12}$ organisasi juga harus membuat kegiatan berbasis pembelajaran Bahasa yang menjadi fokusnya program studi dan kegitan tri dharma perguruan tinggi yang lainnya.

Organisasi mahasiswa yang ada harus mampu melahirkan prestasi mahasiswa, tidak saja hanya di bidang bahasa, akan tetapi juga di bidang lainnya. Minat, bakat, etika, olah raga, dan seni juga harus menjadi prioritas pengembangan organisasi mahasiswa di Prodi Sastra Arab UAI.

\section{Simpulan}

Dari hasil analisis yang dilakukan pada penelitian ini, berikut simpulan yang dapat ditarik, bahwa organisasi mahasiswa intra kampus di Universitas Al Azhar Indonesia, dikelola atas semangat profesionalisme kerja, dengan pendekatan budaya kekeluargaan. Konsep kekeluargaan dipandang tepat dan efektif dalam menjalankan roda organisasi. Bahkan penamaan organisasi intra kampus di UAI juga menggunakan kata keluarga, baik di tingkat universitas, fakultas, program studi dan organisasi minta bakat/UKM.

Ada beberapa program kerja yang dilaksanakan oleh organisasi mahasiswa Prodi Sastra Arab yang menunjang proses pembelajaran kemahiran mendengar, berbicara, membaca dan menulis. Di antara program yang sudah dilaksanakan adalah: keberadaan mading Arab, pelaksanaan Yaumul 'Arabi atau hari bahasa Arab, kursus dan lomba mengetik bahasa Arab, seminar tentang kebahasaan tingkat mahasiswa, jurnalistik, kaligrafi, debat, puisi, menyanyi dalam bahasa Arab, perlombaan dan pertandingan baik lokal, nasional dan internasional dan pelaksanaan festival Arabia serta melaksanakan kegiatan HIMASA mengajar bahasa Arab. Akan tetapi programprogram ini masih perlu untuk ditingkatkan lagi baik dari segi kualitas maupun kuantitas program yang akan dilaksanakan.

Kepedulian mahasiswa untuk aktif di organisasi intra kampus sudah cukup baik, walupun masih ada beberapa yang tidak ingin aktif, adapun penyebab utamanya adalah masih kurangnya rasa memiliki yang muncul dari dalam diri mahasiswa dan kurangnya keilmuan mereka dalam berorganisasi.

Adapun saran untuk pengembangan pembinaan mahasiswa selanjutnya, yaitu: Program Studi perlu melakukan pelatihan secara terprogram dan berkesinambungan yang diperuntukan bagi mahasiswa yang jadi pengurus ataupun calon pengurus. Pelatihan ini dilaksanakan atas kerjasama fakultas, program studi dengan organisasi kemahasiswaan, tujuan utama pelatihan ini agar menjadi alat kaderisasi mahasiswa dalam berorganisasi untuk mengawal organisasi mahasiswa kedepannya. Selain itu, perlu dilakukan usaha persuasif dari Prodi dan organisasi mahasiswa untuk mengingatkan dan menyadarkan mahasiswa yang belum aktif atau malas akan pentingnya untuk aktif dalam organisasi dibawah Prodi Arab.]

${ }^{12}$ Kosasih, "Peranan Organisasi Kemahasiswaan dalam Pengembangan Civic Skills Mahasiswa", JPIS, Jurnal Pendidikan Ilmu Sosial, Vol. 25, No. 2, 2016, 64-74. 
Arabiyât Jurnal Pendidikan Bahasa Arab dan Kebahasaaraban, 5 (1), 2018

\section{DAFTAR RUJUKAN}

Abin, Makmun Syamsududin. Psikologi Pendidikan, Bandung: Remaja Rosdakarya, 1990. Ainin, Mochammad. Metodelogi Penelitian Bahasa Arab, Bandung: Hilal, 2007.

Albantani, Azkia Muharom. Pembelajaran Bahasa Arab di UIN Syarif Hidayatullah Jakarta, Ciputat: Cinta Buku Media, 2018.

Barakah, Zaid. "Diktat Mata Kuliah Metodologi Pengajaran Bahasa Arab", International Institute for Arabic Language, Khartoum, Sudan, 2000.

Bondan, Kreshna W. Cara Cerdas Pilih Jurusan, Demi Profesi Impian, Yogyakarta: Jokya Great, 2010.

Caesari, Yasinta Karina. Anita Listiara. Jati Ariati. "Kuliah versus Organisasi: Studi Kasus Mengenai Strategi Belajar Pada Mahasiswa yang Aktif dalam Organisasi Mahasiswa Pecinta Alam Universitas Diponegoro", Jurnal Psikologi Undip, Vol. 12 No. 2, 2013.

Dardjowidjojo, Soenjono. Psikolinguistik: Pengantar Pemahaman Bahasa Manusia, Jakarta: Yayasan Obor Indonesia, 2008.

Febriana, Betie. dkk. "Hubungan Antara Keaktifan Organisasi dengan Prestasi Belajar (Indeks Prestasi) Mahasiswa Fakultas Ilmu Keperawatan Universitas Indonesia”, Prosiding Konferensi Nasional PPNI Jawa Tengah, 2013.

Gibson \& Ivancevich \& Donnely. Organisasi dan manajemen. Perilaku, struktur, proses. Edisi keempat. Jakarta: Erlangga, 1994.

Kosasih, "Peranan Organisasi Kemahasiswaan dalam Pengembangan Civic Skills Mahasiswa”, JPIS, Jurnal Pendidikan Ilmu Sosial, Vol. 25, No. 2, 2016.

Kurniawati, Rosi. Tino Leonardi. "Hubungan Antara Metakognisi dengan Prestasi Akademik pada Mahasiswa Fakultas Psikologi Universitas Airlangga yang Aktif Berorganisasi di Organisasi Mahasiswa Tingkat Fakultas", Jurnal Psikologi Pendidikan dan Perkembangan, Vol. 2, No. 01, 2013.

Parulian, Hutapea. Nurliana Thoha. Kompetensi Plus, Teori, Desain, Kasus, dan Penerapan untuk HR dan Organisasi yang Dinamis, Jakarta. Gramedia Pustaka Utama, 2008.

Shurna, Wan. Arneliwati Alaihimi, Misrawati. "Perbandingan Prokrastinasi Akademik Berdasarkan Keaktifan Dalam Organisasi Kemahasiswaan”, Jurnal Online Mahasiswa, Vol. 1 No 2, 2014.

Stephen P, Robbins. Timothy A. Judge. Perilaku Organisasi, Buku 1, Jakarta: Salemba Empat, 2008.

Wibowo, Budaya. Organisasi: Sebuah Kebutuban Untuk Meningkatkan Kinerja Jangka Panjang, Jakarta: PT Raja Grafindo Persada, 2011. 